\title{
The Performance Evaluation of Polytechnic Higher Education Institutions: Tensions and Reconfigurations Resulting from the Adoption of Specific Metrics
}

\author{
La Evaluación del desempeño de las instituciones de educación superior \\ politécnica: tensiones y reconfiguraciones resultantes de la adopción \\ de métricas específicas
}

\author{
Sandra Isabel Gonçalves Saúde, Sandra Cristina Santana Lopes, Carlos Manuel Lopes Borralho, \\ Isidro Lourenço Rodrigues Góis Féria'
}

\begin{abstract}
Aligned with the binary structure of the higher education system in Portugal, divided into universities and polytechnics, the Government acknowledged, in 2014, the need to identify distinct performance indicators/metrics aiming at a more accurate assessment of the effect and quality of the action developed by Higher Education Institutions (HEIs). For the Polytechnic Higher Education Institutions (PHEIs) it was necessary to define «(...) performance indicators that address the production, transfer and diffusion of knowledge» (FCT, 2014:1), aiming to measure « $(\ldots)$ the applied research and the cultural production activities as well as their impact on the region where they [PHEIs] are located (...)» (FCT, 2014:1).

Founded on the presentation of specific indicators to be considered when evaluating the performance of PHEIs (developed under a research project funded by FCT: Fundação para a Ciência e a Tecnologia - portuguese national funding agency for science, research and technology), we now focus our reflection on the tensions, reconfigurations and gains for the organizational and educational management that these new metrics can induce.

By successive aggregation, the proposed evaluation indicators allow for the typification and characterization of the separate performance (faculty member/Department/HEI) at the level of applied research, knowledge transfer, population qualification and contribution to the territorial dynamics, which account for the distinct profile of Polytechnics.
\end{abstract}

Keywords

Performance Evaluation, higher education, performance evaluation indicators/metrics.

\section{Resumen}

En línea con la estructura binaria existente en el sistema de educación superior en Portugal, dividido en universidades y escuelas superiores politécnicas, fue identificada, en 2014 por el Ministerio de Educación Superior, la necesidad de identificar los diferentes indicadores/métricas de desempeño que pueden evaluar mejor el efecto y la calidad de la acción desarrollada. En concreto, para las Instituciones de Educación Superior Politécnica (IESP) fue asumido como necesario definir «(...) indicadores de desempeño para la producción, la transferencia y difusión del conocimiento» (FCT, 2014:1), es decir, que permitan evaluar «las actividades de investigación aplicada, de creación cultural y su impacto en las regiones en las que operan (...)» (FCT 2014:1).

Teniendo en cuenta la presentación de indicadores específicos que deben ser considerados en la evaluación de desempeño de las IESP, desarrollados en el ámbito de un proyecto de investigación financiado por la FCT (Fundación para la Ciencia y Tecnología: agencia portuguesa de financiación nacional de la ciencia, investigación y tecnología), centramos, en este artículo, la reflexión sobre el valor añadido y las tensiones que la introducción de nuevas métricas de desempeño, para docentes e instituciones, pueden inducir en la dinámica educativa y organizacional. Los indicadores de evaluación propuestos permiten tipificar y caracterizar la performance de la institución de educación superior en las áreas de la investigación aplicada, de la transferencia de conocimiento y de la contribución para la dinámica socioeconómica del territorio en el que opera.

\section{Palabras clave}

Evaluación del desempeño; educación superior; indicadores/métricas de evaluación del desempeño.

\footnotetext{
1 Interdisciplinary Centre of Social Sciences, University of Évora - CICS.NOVA.UÉvora, Polytechnic Institute of Beja, Portugal, Sandra Isabel Gonçalves Saúde, ssaude@ipbeja.pt; Sandra Cristina Santana Lopes, slopes@ipbeja.pt; Polytechnic Institute of Beja, Carlos Manuel Lopes Borralho, cborralho@ipbeja.pt; Isidro Lourenço Rodrigues Góis Féria, iferia@ipbeja.pt.
} 


\section{Introduction}

The project Performance Indicators for Polytechnic Higher Education Institutions we now present was carried out between October 2014 and February 2016, funded by FCT - Fundação para a Ciência e a Tecnologia (Portuguese national funding agency for science, research and technology) as a result of a program launched in 2014 by the Portuguese Ministry of Education and Science. It was developed as a partnership between researchers of the Polytechnic Institute of Beja, the University of Aveiro and the Centre for Research in Higher Education Policies (CIPES - Centro de Investigação em Políticas do Ensino Superior). This study involves the validation and consensualisation of performance evaluation indicators organized around five essential dimensions of the mission of Higher Education Institutions (HEIs), specifically the Polytechnics (PHEI):

a) services provided,

b) knowledge transfer,

c) scientific and artistic production,

d) collaborative research,

e) societal impact.

The validation of the evaluation indicators for each dimension included the hearing of the heads of PHEIs, through e-Delphi, in a first moment, then ratified by case studies, in a second phase. In this paper we will share the main results of this process.

\section{Performance evaluation of Higher Education Institutions}

\subsection{Performance evaluation of Higher Education Institutions in Portugal - recent trends}

Reflection around performance indicators for Higher Education Institutions (HEIs) in Portugal starts with the discussion and publication of the revised formula for Higher Education funding in Law $37 / 2003$. This Law entails the termination of the standard budget concept (existing since 1997), by establishing that the financing of HEIs should be based on a reference budget, calculated by a funding formula covering objective criteria of quality and excellence, standard values and performance indicators (Law 37/2003).

Since the relation between performance and funding has not been consolidated through time, the reflection on the importance and viability of estimating the outputs generated by HEIs was buried in doubts of a political nature in what concerns the real interest and practicability of this process.

It has been hard indeed to assume, at the political level, that it is necessary to substitute a paradigm that associates public funding with institutional history and input indicators (namely the number of students) with one that focuses on performance indicators and the outputs generated by the institution. Besides the reflection around the most suitable indicators, there is also the absence of a standardized methodology to collect the data on some domains of the activity of HEIs and the need for greater clarity on the part of the Ministry about a framework of principles, objectives and purposes for the performance evaluation of HEIs.

At the moment, the performance evaluation of HEIs is mainly evident in the aims and scope of the Agency for Evaluation and Accreditation of Higher Education (A3ES - Portuguese acronym), 
which, for purposes of evaluation and accreditation of the educational offer of HEIs, evaluates a set of performance indicators particularly associated with pedagogical expertise and the capacity of scientific production versus knowledge transfer, within the domain of the course under scrutiny. Over the past four years, while implementing the audit and certification of internal systems which guarantee the quality of HEIs, the A3ES has given a valuable contribution to consolidate a culture of evaluation, demonstrating that the path to implement and collect a systematic set of performance indicators is under way, in Portugal.

\subsection{Polytechnic Higher Education and its performance evaluation metrics}

Based on international studies and evaluation programs, developed by the OECD ${ }^{2}$ and ENQA ${ }^{3}$, in 2006, the Portuguese government in effect, aware of the need to boost a reform of the sector, issued a new Legal Regime for Institutions of Higher Education (RJIES - Portuguese acronym). Law $62 / 2007$ confirmed the binary structure of Portuguese higher education, divided into the university and polytechnic subsystems.

Under this legal framework, each of the subsystems must comprehend specific ontological codes and curricula. This way, university education must aim at «the provision of sound academic training, combining the efforts and skills of both teaching and research units» (RJIES, 2007, article $6^{\text {th }}: 6359$ ), while polytechnic education, essentially practical and experimental in nature, should especially concentrate on «vocational and advanced technical training, both professionally-oriented» (RJIES, 2007, article $7^{\text {th }}:$ 6359).

This legal framework is reinforced by the latest manifestations of both the Parliament and the two last governments, evidenced in recent legal and political publications. Parliament Resolution 77/2013 urges the Government to: «1. Clearly strengthen the binary model, clarifying the specific missions of university and polytechnic higher education; 2. Promote the regional articulation of synergies within the scope of the training provided, thus discouraging the mimetism between subsystems (...).» (Resolução da Assembleia da República 77/2013:3234). The State Reform Guide, published on October $30^{\text {th }} 2013$, on the other hand, establishes the need for «(...) a reform of Higher Education, aiming at improving the quality of university education and consolidating the polytechnic educational offer (...)» (Guião da Reforma do Estado, 2013:76).

More recently, the current Minister for Science, Technology and Higher Education announced his interest in «(...) differentiating the evaluation of universities and polytechnic institutions» (MCTES, June $8^{\text {th }}$ 2016: 6) and highlighted «(...) the need to increase the distinction between universities and polytechnics, from aims and contents to their individual missions», in a debate promoted among all the actors of higher education (Online Newspaper Observador, July 18 $8^{\text {th }}$ 2016).

It is consensual that to evaluate the performance of PHEIs, the simple application of traditional indicators is far from enough. Indicators such as the number of papers produced, the number of researchers belonging to research centres (in the Portuguese situation, those accredited by the FCT) or the number of citations in scientific papers by teacher/researcher, generally used to evaluate teaching staff performance in the university system, are rather insufficient and even inappropriate in what polytechnic higher education is concerned.

2 Organisation for Economic Co-operation and Development.

3 European Association for Quality Assurance in Higher Education. 
It seems therefore important to contribute to the adjustment of evaluation metrics to the characteristics of the outputs generated by PHEIs. This was the key objective of the work developed within this project, namely: to identify and develop performance indicators for the production, transfer and diffusion of knowledge of PHEIs.

\section{The Project}

\subsection{Methodology}

The challenge to identify performance indicators for PHEIs implied the development of a process which occurred in five stages (see Table 1), from the selection and construction of more adjusted indicators, according to the existing scientific literature and the suggestions of the key informants consulted, to, at a final stage, their validation and applicability test.

In Stage I the team collected existing indicators for the evaluation of the performance of PHEIs, with special focus on applied research, cultural production and societal impact. Several reference works, produced both in the national and international contexts, were consulted and analysed, including:

i) the indicators applied by the Agency for Evaluation and Accreditation of Higher Education (A3ES) when evaluating and accrediting the courses,

ii) projects U-Map e U-Multirank, funded by the European Union, and project E3M - European Indicators and Ranking Methodology for University Third Mission,

iii) the work developed by CHEPS - Measuring performance of applied R\& D. A study into performance of applied R\&D in the Netherlands and some other countries, and by UASnet - The EDUPROF project: developing indicators of applied research. Final Report. Full list of works consulted to be found in footnote 4 .

In addition, we carried out a review of the literature on higher education, focusing on the coexistence of two subsystems - typical of some European countries, including Portugal - and the extent to which the differentiation of missions can be depicted by the preponderance of different research modalities associated with each of the subsystems: fundamental research in the university subsystem and applied research in the polytechnic context.

4 Bornman, Lutz (2012). «Measuring the societal impact of research. Research is less and less assessed on scientific impact alone - we should aim to quantify the increasingly important contributions of science to society». EMBO reports, 13, 673- 676. DOI 10.1038/embor.2012.99

Deen, Jarno y Vossensteyn, Hans (2006). Measuring performance of applied ReD. A study into performance of applied ReD in the Netherlands and some other countries. Enschede: Center for Higher Education Policy Studies (CHEPS)/Universiteit Twente. Retrieved from https://www.utwente.nl/bms/cheps/publications/publications\%202006/engreport06measuringperformance.pdf on $18^{\text {th }}$ September 2016.

Finne, Håkon et al., (2011). A composite indicator for knowledge transfer. Report from the European Commission's expert group on knowledge transfer indicators. Luxembourg: European Union Publications. Retrieved from https://ec.europa.eu/research/innovation-union/pdf/kti-report-final.pdf on $18^{\text {th }}$ September 2016.

Healy, Adrian et al., (2014). Measuring the impact of university-business cooperation. Final Report. Luxembourg: European Union Publications. Retrieved from http:// ec.europa.eu/dgs/education_culture/repository/education/library/study/2014/university-business_en.pdf on $18^{\text {th }}$ September 2016.

REF 2014 (2011). Assessment Framework and guidance on submissions. Retrieved from http://www.ref.ac.uk/media/ref/content/pub/assessmentframeworkandguidanceonsubmissions/GOS\%20including\%20addendum.pdf on $18^{\text {th }}$ September 2016.

UASnet (2011). The EDUPROF project: developing indicators of applied research. Final Report. Retrieved from http://www.scienceguide.nl/media/700624/eduprof_report_november_2011.pdf on 18 $8^{\text {th }}$ September 2016. 
Table I. Project stages, techniques and objectives by stage

\begin{tabular}{|c|c|c|}
\hline STAGES & TECHNIQUES & OBJECTIVES \\
\hline Stage I & Documental analysis & $\begin{array}{l}\text { (i) to analyse and reflect upon the state of the art on perfor- } \\
\text { mance evaluation of HEls } \\
\text { (ii) to ensure that the indicators to be constructed relate to } \\
\text { existing indicators used by PHEls } \\
\text { (iii) to draft the theoretical framework supporting the composition } \\
\text { of the indicators to propose }\end{array}$ \\
\hline Stage II & Semi-structured interviews and Focus Group & $\begin{array}{l}\text { (i) to listen to the positions of the PHEl representatives on the } \\
\text { proposed dimensions and performance indicators, according } \\
\text { to the specific characteristics of their institutions } \\
\text { (ii) to promote the discussion between the representatives of the } \\
\text { various institutions in order to assess the most appropriate } \\
\text { way to measure institutional performance regarding the } \\
\text { proposed dimensions } \\
\text { (iii) to discuss, justify and ratify, with the project consultants, the } \\
\text { indicators previously identified through documental analysis }\end{array}$ \\
\hline Stage III & Triangulation of data resulting from Stages I and II & $\begin{array}{l}\text { (i) to analyse and gather consensus on the final list of indicators } \\
\text { to be validated with the PHEls, through the e-Delphi method }\end{array}$ \\
\hline Stage IV & e-Delphi & $\begin{array}{l}\text { (i) to validate the final version of the analysis dimensions and } \\
\text { respective indicators, with the heads of the PHEls, both public } \\
\text { and private }\end{array}$ \\
\hline Stage V & $\begin{array}{l}\text { Direct observation and Structured interviews applied to selected } \\
\text { cases }\end{array}$ & $\begin{array}{l}\text { (i) to test the feasibility and applicability of the final list of } \\
\text { validated indicators on which consensus was reached, by } \\
\text { applying the e-Delphi method, in } 4 \text { PHEls selected according } \\
\text { to particular key characteristics, namely: size, geographic } \\
\text { location, mono or multidiscippinary profilie, and area covered }\end{array}$ \\
\hline
\end{tabular}

Source: the authors.

In Stage II, various stakeholders of the polytechnic higher education system were surveyed, through a set of semi-structured interviews, first with the state secretary, on the scenarios for the use of indicators, and, later, with heads of some PHEIs, trying to validate, together with them, a proposal of dimensions and indicators which made it possible to estimate applied research, cultural production and societal impact. With this latter group of interviewees we tried to include some diversity and randomness aiming to obtain representativity of the sample, regarding the size, geographic location and organizational characteristics (public or private) of the PHEIs. In effect semi-structured interviews were applied to six heads of polytechnic institutes and schools, both public and private.

After the interviews, a workshop was held to which the heads of all Portuguese PHEIs were invited (of the public and private sectors, both polytechnic institutions and higher schools integrated in universities). The objective of this meeting was, once again, to promote a discussion among the representatives of the various institutions in order to assess the most accurate way of measuring the performance of PHEIs in applied research, cultural production and societal impact activities. The workshop was attended by 18 representatives of 15 PHEIs.

Within this second stage, three thematic meetings took place, focusing on the performance evaluation of HEIs, with a team of consultants from the University of Alcalá de Henares and the University of Lleida, specially chosen for this purpose for their recognized experience in HEI administration and the development of indicators to evaluate the effects generated by HEIs. During these meetings, various indicators were discussed, theoretically justified and chosen, both deductively and inductively. By resorting to critical analysis and consensus decision-making, it was possible to construct and reconstruct a substantiated provisional list of indicators adjusted to our purpose. 
In Stage III it was necessary to reach consensus on the performance measurement dimensions and indicators. It was relatively easy to find consensus around a final list of 29 indicators, which would eventually be submitted to validation through the e-Delphi method.

The e-Delphi technique was used in Stage IV, with the objective of reaching consensus and a decision on the final validation of the performance indicators, among the heads of the PHEIs, belonging to the polytechnic subsystem, both public and private. This technique is a qualitative research tool that seeks to gather consensus from a panel of experts on a theme or future event. Such consensus is based on the principle that the intuitive judgment from a structured group of experts, previously selected, is far more accurate than that of an individual or an unstructured group with no expertise (Hsu y Sandford, 2007).

Finally, in Stage $V$, aiming to test the feasibility and applicability of the list of consensualized and validated indicators through the e-Delphi technique, four PHEIs were selected to carry out a set of exploratory studies. The selection aimed to guarantee the diversity of institutions (public, private, polytechnic institutions, higher schools integrated in universities and non-integrated higher schools, mono and multi-disciplinary, located in different regions and with different dimensions in terms of number of students). The interaction with the PHEIs (through direct observation and semi-structured interviews) provided global and specific assessment for each indicator concerning the difficulty to collect the data, the applicability of the calculation formula, its feasibility, as well as the identification of specific resistance against the calculation of the final indicators).

\subsection{The results: final list of indicators obtained through e-Delphi}

To collect the opinion of the heads of the PHEIs on the performance indicators proposed, a questionnaire survey was designed, following the principles and procedures of the e-Delphi technique. The 29 performance evaluation indicators initially identified were organized around 5 dimensions within the range of activities of polytechnic institutions. The evaluation of each indicator used a likert scale of 6 points (from Totally inadequate to Totally adequate) supported by six analysis criteria, namely:

- Relevance: the degree to which the indicator is considered adequate to assess the performance of a PHEI.

- Clarity: degree to which it may be easily understood by everyone.

- Measurability: degree to which it can be measured.

- Traceability: degree to which it is considered to be auditable.

- Aggregation/Disaggregation: degree to which it is considered to be subject to aggregation or disaggregation from the individual level (faculty) to that of the PHEI.

- Efficiency of data collection: how easy it is to collect and calculate the data in terms of time and resources used.

The first round of questionnaires obtained 33 valid answers: 16 from public PHEIs and 17 from private ones, corresponding to a return rate of $48.5 \%$.

The second round focussed on 25 indicators and was addressed only to the heads of the PHEIs who had answered in the first round. In this second round a total of 25 valid answers was obtained, 13 from public institutions and 12 from private ones. This corresponds to a percentage of 72.7 . 
The list of final indicators that obtained greater consensus among the heads of the PHEIs is as follows:

\section{Table II. Final List of Performance Indicators}

DIMENSION 1: PROVISION OF SERVICES

\section{Indicator 1: Percentage of income generated from Services provided}

Objective: To measure the relative weight of the income generated by the PHEl from activities related to consultancy, provision of services and professional development courses or specialization programs not integrated in undergraduate or master's degrees or CTSP (short-cycle tertiary education).

\section{Calculation Formula}

[Revenue from Services provided by the PHEl, including continuous education programs]/[0perating budget of the PHEI]

(on $31 / 12$ of $\mathrm{N}-1$ )

DIMENSION 2: SCIENTIFIC AND ARTISTIC PRODUCTION

Indicator 2: Percentage of income generated by Research

Objective: To measure the relative weight of the revenue generated by the PHEl from Research.

Calculation Formula

[Revenue obtained by the PHEl from Research]/[Operating budget of the PHEI]

(on $31 / 12$ of $\mathrm{N}-1$ )

Indicator 3: Research effort rate by full-time faculty member

Objective: To measure the dedication and involvement of the teaching staff regarding research activities.

Calculation Formula

[Total \% of time devoted to research by the PHEl faculty staff]/[Number of full-time faculty staff of the PHEl]

(on $31 / 12$ of $\mathrm{N}-1$ )

Indicator 4: Peer-reviewed scientific production by full-time faculty member

Objective: To measure the scientific production by full-time faculty member.

Calculation Formula

[Average number (in the last 3 years) of peer-reviewed publications indexed to SCOPUS, in which at least one author is a member of the PHEl and the other authors possess an academic institutional address] [Average number of full-time faculty staff in the last 3 years]

(average in the last 3 years calculated from $31 / 12$ of $N-3$ to $31 / 12$ of $N-7$ )

Indicator 5: Artistic production by full-time faculty member

Objective: To measure the artistic production by full-time faculty member.

Calculation Formula

[Average number (in the last 3 years) of artistic outputs, in which at least one author is a member of the PHEl and the other authors possess an academic institutional address]/[Average number of full-time faculty staff in the last 3 years]

(average in the last 3 years calculated from $31 / 12$ of $N-3$ to $31 / 12$ of $\mathrm{N}-1$ )

Indicator 6: Impact of the scientific production by full-time faculty member

Objective: To measure the impact of the scientific production by full-time faculty member.

Calculation Formula

[Average number (in the last 3 years) of citations from publications indexed to SCOPUS, in which at least one author is a member of the PHEl and the other authors possess an academic institutional address] / [Average number of full-time faculty staff in the last 3 years]

(average in the last 3 years calculated from $31 / 12$ of $\mathrm{N}-3$ to $31 / 12$ of $\mathrm{N}-1$ )

Indicator 7: Revenue for academic research by full-time faculty member

Objective: To estimate the global amount of funding obtained from research projects approved by national and international agencies, non-profit institutions, foundations, among other, weighted by the number of full-time academic staff.

\section{Calculation Formula}

[Revenue from research carried out by the PHEI]/[Number of full-ime faculty staff of the PHEI]

(on $31 / 12$ of $\mathrm{N}-1$ ) 


\section{DIMENSION 3: COLLABORATIVE RESEARCH}

\section{Indicator 8: Percentage of the income devoted to collaborative research}

Objective: To quantify the research developed in collaboration with companies or other non-academic organizations, public or private.

\section{Calculation Formula}

[Income of the PHEl from research projects resulting from partnerships with external non-academic entities]/[Revenue from the PHEl research]

(on $31 / 12$ of $\mathrm{N}-1$ )

\section{Indicator 9: Co-patents per PHEI}

Objective: To measure the capacity to produce knowledge with commercial application potential, in parnership with external non-academic entities.

Calculation Formula

[Average number (in the last 3 years) of patents of the PHEl, in which at least one of the holders belongs to an external non-academic organization] /[Average number of full-time faculty staff in the last 3 years]

(average in the last 3 years calculated from $31 / 12$ of $\mathrm{N}-3$ to $31 / 12$ of $\mathrm{N}-1$ )

\section{Indicator 10: Scientific production with non-academic partners by full-time faculty member}

Objective: To measure the scientific production in collaboration with external non-academic organizations.

[Average number (in the last 3 years) of academic publications indexed to SCOPUS, by the PHEl aca-

Calculation Formula demic staff, in which at least one author has a non-academic institutional address]/[Average number of the PHEl full-time faculty staff in the last 3 years]

(average in the last 3 years calculated from $31 / 12$ of $\mathrm{N}-3$ to $31 / 12$ of $\mathrm{N}-1$ )

Indicator 11: Artistic Production with external non-academic entities by full-time faculty member

Objective: To measure the artistic production in collaboration with external non-academic entities.

Calculation Formula

[Average number (in the last 3 years) of artistic outputs of the PHEl with external non-academic entities]/[Average number of full-time faculty staff of the PHEl in the last 3 years]

(average in the last 3 years calculated from $31 / 12$ of $\mathrm{N}-3$ to $31 / 12$ of $\mathrm{N}-1$ )

\section{Indicator 12: Global funding allocated to R\&D for collaborative research by full-time faculty member}

Objective: To measure the funding or co-funding amounts allocated to research projects with companies or other non-academic organizations, public or private, by full-time faculty member.

Calculation Formula

Revenue from collaborative research developed by the PHEI]/[Number of full-time faculty staff of the PHEl]

(on $31 / 12$ of $\mathrm{N}-1$ )

Indicator 13: Post-graduate students involved in collaborative research carried out with non-academic partners

Objective: To measure the capacity of the PHEl to promote research developed by the students in companies or other non-academic organizations, public or private.

\section{Calculation Formula}

[Number of post-graduate students of the PHEl co-funded and/or co-supervised by non-academic organizations] /[Number of post-graduate students of the PHEl]

$$
\text { (on } 31 / 12 \text { of } \mathrm{N}-1 \text { ) }
$$

DIMENSION 4: KNOWLEDGE TRANSFER

\section{Indicator 14: Patents by PHEI}

Objective: To measure the capacity to produce knowledge with commercial application potential.

Calculation Formula
[Average number (in the last 3 years) of patents of the PHEl, in which all the holders belong to academic institutions]/[Average number of full-time faculty staff in the last 3 years]

(average in the last 3 years calculated from $31 / 12$ of $\mathrm{N}-3$ to $31 / 12$ of $\mathrm{N}-1$ )

\section{Indicator 15: Revenue from royalties and licensing agreements}

Objective: To estimate the PHEl capacity to generate income from knowledge transfer activities.

\section{Calculation Formula}

[Average income (in the last 3 years) from royalties and intellectual property licensing agreements of the $\mathrm{PHEI} /[$ Aaverage number of full-time faculty staff in the last 3 years]

(average in the last 3 years calculated from $31 / 12$ of N-3 to $31 / 12$ of $N-1$ ) 
DIMENSION 5: SOCIETAL IMPACT

(indexed to the impact generated in the regions where the PHEl is located)

Indicator 16: Contribution to the qualification of the active population of the NUTS (Nomenclature of Territorial Units for Statistics) $3^{5}$

Objective: To measure the contribution of the PHEl to the qualification of the active population of the region where it is located (NUTS 3).

\begin{tabular}{ll}
\hline & [Number of working students enrolled in the PHEI]/[Working-age population with no higher education \\
Calculation Formula & qualifications of the NUTS 3 where the PHEl is located] \\
& (numerator on $31 / 12$ of $\mathrm{N}-7$ and denominator on the last census) \\
\hline
\end{tabular}

Indicator 18: Contribution to the qualification of the NUTS 3 resident population

Objective: To measure the contribution of the PHEl to meet one of the targets of Europe 2020 strategy at the regional level: $40 \%$ of the population aged $30-34$ having a higher education diploma.

[Average number (in the last 3 years) of graduates of the PHEl, aged 30-34 residing in the NUTS 3]/
[Average number (in the last 3 years) of all residents of the NUTS 3, aged 30-34]

(Average numbers in the last 3 years, calculated from $31 / 12$ of $N-3$ to $31 / 12$ of $N-1$ )

Indicator 19: Capacity to attract a young population to the NUTS 3

Objective: To measure the capacity of the PHEl to attract a young population to the region where it is located (NUTS 3).

\begin{tabular}{ll}
\hline Calculation Formula & [Number of students of the PHEl aged 20-24 coming from outside the NUTS 3]/[Number of residents \\
in the NUTS 3 aged 20-24] & (on 31/12 of N-1)
\end{tabular}

Indicator 20: Capacity to renovate / requalify the workforce of the NUTS 3

Objective: To measure the contribution of the PHEl to the renovation/requalification of the workforce of the region where it is located.

Calculation Formula

[Average number (in the last 3 years) of graduates of the PHEl (bachelor's and master's graduates), employed in the NUTS 3]/[Average number (in the last 3 years) of the employed population of the NUTS 3]

(Average numbers in the last 3 years, calculated from $31 / 12$ of N-3 to $31 / 12$ of N-7)

\section{Indicator 21: Capacity to retain the NUTS 3 human capital}

Objective: To measure the contribution of the PHEl to retain its graduates in the region where it is located (NUTS 3).

Calculation Formula
[Average number (in the last 3 years) of graduates of the PHEl (bachelor's and master's graduates), employed in the NUTS 3]/[Average number (in the last 3 years) of all graduates of the PHEI (bachelor's and master's graduates)]

(Average numbers in the last 3 years, calculated from $31 / 12$ of N-3 to $31 / 12$ of N-1)

Indicator 22: Business practices and job placement of graduates

Objective: To measure the adjustment between the training provided by the PHEl and the labor market demands of the region where it is located.

[Average number (in the last 3 years) of academic internships of the PHEl undergraduates which led

Calculation Formula to professional internships and/or actual job placements]/[Average number (in the last 3 years) of academic internships of the PHEl undergraduates]

(Average numbers in the last 3 years, calculated from $31 / 12$ of $\mathrm{N}-3$ to $31 / 12$ of $\mathrm{N}-1$ )

Indicator 23: Contribution to social dynamics

Objective: To measure the contribution of the PHEl to the regional social dynamics.

Calculation Formula
[Number of PHEl faculty who participate in scientific committees, juries of local awards, local and regional councils or as members of governing bodies of local institutions] / [Number of full-ime faculty staff]

(on $31 / 12$ of $\mathrm{N}-1$ )

Source: the authors

\subsection{Applicability test on the list of indicators}

In the last stage of this project it was fundamental to apply a complementary test on the applicability of the list of performance indicators with 4 PHEIs. The objective of this step was to assess the practicability of the calculations and to obtain some final considerations on the relevance of the final proposal.

$\overline{5}$ Specific information at: http://ec.europa.eu/eurostat/web/nuts/overview 
The PHEIs were selected according to certain differentiating characteristics, as follows:

- the sector to which they belong - public or private

- geographic location - dispersed across the country, located in large or small urban areas

- training profile - mono or multidisciplinary

- size of the academic community - students, teaching and non-teaching staff

- organizational structures with different degrees of complexity

The heads of the PHEIs were surveyed through semi-structured interviews on: (i) global and specific assessment for each indicator; (ii) main difficulties felt when applying the calculation formulae; (iii) possible difficulties to collect the data; (iv) challenges the model presents as a performance evaluation tool for PHEIs, as well as a management support mechanism. The following are some of the highlights of this global assessment:

\section{- Traceability, comparability and clarity of indicators}

According to the heads of the PHEIs surveyed, the indicators respect the fundamental criteria for performance evaluation and meet the criteria for traceability, clarity and comparability. Besides, they can be easily calculated by resorting to official sources.

- Validation of the dimensions and recognition of their effective contributions to prospective institutional management

The recognition of the existence of distinct institutional profiles through the positioning of each PHEI regarding the five dimensions analysed is unanimous and supports the comments made during the e-Delphi rounds. The institutional perception of the place where the PHEI is located, when crossed with its performance in each of the dimensions, may contribute to the design of a more efficient development strategy in future, since the governing body can opt for investing more in a particular dimension. The proposed evaluation tool was, therefore, considered relevant in the perspective of institutional performance monitoring metrics, at the level of management, at the micro, meso or macro levels, in the field of organizations.

- Recognition of the importance of performance evaluation metrics as an aid to management, rather than a tool for a state funding formula

In general, everyone acknowledged the merit of the indicators proposed as an aid for management; however, it must not be used as the basis for a funding formula for PHEIs. This debate is related to the fact that the list of indicators includes several variables that are not controllable or controlled by PHEIs, and, if used, may contribute to a deeper gap between institutions with very different contexts and profiles - resulting, as was mentioned before, from different strategic options in each of the dimensions, which account for their specific standard profiles.

It was also pointed out by some of the participants that the adoption of such a model for evaluating the performance of PHEIs would imply a necessary institutional adjustment in accordance with the specificities of each PHEI.

\section{- Need to include other bibliographic databases besides SCOPUS}

The use of SCOPUS as the only source for counting publications was considered questionable and limited. It was suggested that a more comprehensive list of databases (with an associated qualitative evaluation grid) be created, including, not only the publications indexed to SCOPUS, 
but also, for example, those indexed to SciELO or Latindex, as well as books and/or chapters of books existing in scientific repositories.

\section{- Impossibility to include projects of a different nature, which don't generate a financial return}

When evaluating a PHEI, there should be a way of including projects of high societal impact even if they don't necessarily generate a financial return. For some of the representatives of the PHEIs included in this stage of the project, the focus on the financial return of projects/activities is considered a form of pressure which may divert the focus of the PHEIs' public mission (mainly in what concerns education and training). Also associated with financial management, the PHEIs argue that there is no autonomy to strategically allocate their own revenues. According to some of the interviewees, a greater degree of autonomy would allow them to strengthen their institutional profile, by deciding on the investment or the allocation of resources to a particular sector of the institutional dynamics.

- Recognition that the societal impact of some indicators must be measured beyond the mere indexation to the NUTS 3

The NUTS 3, as geographic indexation regions, were considered a limitation, due to the real societal impact of some PHEIs, since the profile of their educational offer provides qualification well beyond the NUTS 3. Therefore, widening the regional scope to include the NUTS 2 and/ or NUTS 1 was suggested, especially for employability indicators. It was also considered that the capacity of the PHEI to attract students should remain focused on the NUTS 3. Even so, it is expected that PHEIs located in more developed areas and in large urban centres have a competitive advantage over those located in interior regions (and islands), more desertified and characterized by a lower supply of services, housing, transports and cultural or leisure offer.

\section{Conclusions}

According to the results obtained, the list of indicators proposed was accepted as a good model for monitoring the performance of PHEIs and their faculty staff in relation to key indicators and dimensions, not properly covered in the existing organizational evaluation instruments so far. It should be regarded as an important tool to support the strategic management of the institution, since it identifies the dimensions in which the PHEI needs to improve.

Even though these indicators are mainly of a quantitative nature, it is argued that the management of the organizational performance must not be limited to this aspect. This quantitative approach should be complemented by parameters of a qualitative nature, sustained, for example, in success stories, which may show differentiating trajectories of PHEIs.

\section{References}

ENQA (2006). Quality Assurance of Higher Education in Portugal An Assessment of the Existing System and Recommendations for a Future System. Retrieved from http://www.enqa.eu/pubs.lasso, on $18^{\text {th }}$ September 2016.

FCT (2014). Public notice for funding of projects aiming at the development and validation of performance indicators for the production, transfer and diffusion of knowledge of PHEIs. Retrieved from http://www.fct.pt/apoios/outros/indicadores/docs/Edital.pdf, on 14 ${ }^{\text {th }}$ February 2017. 
Guião da Reforma do Estado (State Reform Guide) (2013). Retrieved from https://pt.scribd.com/document/180306383/Guiao-da-Reforma-de-Estado\#download\&from_embed on 14 ${ }^{\text {th }}$ February 2017.

Hsu, Chia-Chien \& Sandford, Brian A. (2007): "The Delphi Technique: Making Sense Of Consensus. Practical Assessment.” Research \& Evaluation, 12, 1-8.

MCTES (Ministério da Ciência, Tecnologia e Ensino Superior) (2016). Intervenção do Ministro da Ciência, Tecnologia e Ensino Superior no Debate temático no Conselho Nacional de Educação sobre ciência, tecnologia e ensino superior no âmbito da apresentação do Plano Nacional de Reformas. Retrieved from http://www.portugal.gov.pt/media/19856265/20160608-mctes-plano-nacional-reformas.pdf on $14^{\text {th }}$ February 2017.

OCDE (2006). Tertiary Education in Portugal. Background Report. Retrieved from http://www.oecd. org/portugal/39710472.pdf, on 18 ${ }^{\text {th }}$ September 2016.

Resolução da Assembleia da República 77/2013 (Parliament Resolution 77/2013). Diário da República, $1 .^{a}$ série - N. ${ }^{o} 110,3234$. Retrieved from https://dre.pt/application/file/496653 on $14^{\text {th }}$ February 2017.

RJIES. Regime jurídico das instituições de ensino superior (Legal system of higher education institutions) (2007). Lei n. ${ }^{\circ}$ 62/2007 de 10 de setembro. Diário da República, 1. ${ }^{a}$ série - N. ${ }^{0}$ 174, 6358 - 6389. Retrieved from https://sigarra.up.pt/fpceup/pt/legislacao_geral.ver_legislacao?p_nr=316 on $14^{\text {th }}$ February 2017.

\section{Notas biográficas}

Sandra Saúde es Profesora del Departamento de Educación, Ciencias Sociales y del Comportamiento -Instituto Politécnico de Beja e Investigadora del CICS. Nova (Centro Interdisciplinario de Ciencias Sociales CICS. NOVA - FCSH/UNL), Portugal. Principales intereses de investigación: planificación y estrategia organizacional, evaluación de resultados organizacionales y de impactos socioeconómicos. Publicaciones recientes: Saúde, S., et al., (2014). Os impactos Socioeconómicos do Ensino Superior: um retrato a partir de estudos de caso de Portugal e Espanha. Lisboa: Edições Sílabo; Saúde, S., et al., (2017). Indicadores de Desempenho para as Instituições de Ensino Superior Politécnico. Investigação Aplicada, Criação Cultural e Impacto regional. Lisboa: Edições Sílabo.

Sandra Lopes es Profesora del Departamento de Educación, Ciencias Sociales y del Comportamiento - Instituto Politécnico de Beja, Portugal. Principales intereses de investigación: demografía, cultura y territorio y planificación estratégica. Publicaciones recientes: Saúde, S., et al., (2014). Os impactos Socioeconómicos do Ensino Superior: um retrato a partir de estudos de caso de Portugal e Espanha. Lisboa: Edições Sílabo; Saúde, S.; Borralho, C.; Féria, I.; Lopes, S. et al., (2017). Indicadores de Desempenho para as Instituciones de Ensino Superior Politécnico. Investigación Aplicada, Criação Cultural E Impacto regional. Lisboa: Edições de Sílabo.

Carlos Borralho es Profesor Invitado del Departamento de Ciencias Empresariales - Instituto Politécnico de Beja, Portugal. Áreas de investigación actual: gobierno electrónico, negocio electrónico y CRM (gestión de la relación con el cliente), y evaluación de impactos socioeconómicos de organizaciones o eventos. Publicaciones recientes: Borralho, C.; Pires, C. e Basílio, M. (2016). Casos Empresariais de Sucesso no 
Baixo Alentejo y Alentejo Litoral. Lisboa: Chiado Editora.; Saúde, S.; Borralho, C.; Féria, I.; Lopes, S. et al., (2017). Indicadores de Desempenho para as Instituciones de Ensino Superior Politécnico. Investigación Aplicada, Criação Cultural E Impacto regional. Lisboa: Edições de Sílabo.

Isidro Féria es Profesor del Departamento de Ciencias Empresariales - Instituto Politécnico de Beja, Portugal. Principales intereses de investigación: modelos de financiación para los sistemas de educación superior y de control presupuestario; evaluación de los resultados organizacionales y evaluación de impactos socioeconómicos. Publicaciones recientes: Saúde, S.; Borralho, C.; Féria, I. y Lopes, S. (2014). "El impacto de la Educación Superior en el Desarrollo Socioeconómico: El estudio de caso del Instituto Politécnico de Beja, Portugal”. Copernican Journal of Finance \& Contabilidad. Polonia: Universidad Nicolás Copérnico, Torún. Vol. 3, n. ${ }^{\circ}$ 2; Saúde, S.; Borralho, C.; Féria, I. y Lopes, S. (2013). O impacto socioeconómico do IPBeja no concelho de Beja. Porto: IPBeja/Norprint. 